\title{
Use of the 2008 Basel Consensus Statements to Assess, Realign, and Monitor Pharmacy Practice at a Tertiary Care Hospital in Northern Uganda: Illustrative Case Study, Part 2
}

\author{
Danielle Stacey, Régis Vaillancourt, Lisa Brander, Nathalie Chenel, Elizabeth McMahon, \\ Jennifer Wiebe, Allison Kirkwood, Ghada Shaka, and Doret Cheng
}

\section{INTRODUCTION}

Ct Mary's Lacor Hospital (Lacor Hospital), located in the $\checkmark$ Gulu District of Northern Uganda, was founded in 1959 by a group of Comboni missionaries and was later developed and expanded by a Canadian surgeon, Dr Lucille Teasdale, and an Italian pediatrician, Dr Piero Corti. ${ }^{1}$ The hospital grew from a 30-bed hospital to a 483-bed health care centre, providing care to about 500 inpatients and 800 outpatients daily. Lacor Hospital also supports and operates 3 peripheral 24-bed health centres, each about $10 \mathrm{~km}$ from the hospital, to serve the villages surrounding Pabbo, Opit, and Amuru. The hospital has become a training ground for various health care professionals, including students from the faculties of medicine and pharmacy and the midwifery programs of Gulu University, Makerere University, and Mbarara University. In addition, the Lacor School of Nursing and Lacor School of Laboratory Technology were developed within the hospital. In 2009, the hospital's executive team identified the need for the Department of Pharmacy to establish optimal strategies for logistical support and technical assistance with regard to medication management and pharmacy practice.

The challenges highlighted at Lacor Hospital parallel the vision of the World Health Organization (WHO) and the International Pharmaceutical Federation (FIP) of optimizing patient safety, utilizing health care resources responsibly, and ensuring the integrity of the medication supply chain. ${ }^{2}$ In 2009 , Pharmaciens sans frontières (also known as Pharmacists Without Borders-Canada or PSF-Canada) was contracted by the Teasdale-Corti Foundation and the Lacor Hospital executive team to provide pharmacy support, knowledge exchange, and technical assistance to the Lacor Hospital
Department of Pharmacy. ${ }^{1}$ Two PSF-Canada pharmacists (including R.V.) conducted the initial on-site evaluation, which resulted in 24 recommendations aligned with the FIP's 2008 Basel Statements on the future of hospital pharmacy (Table 1). The recommendations presented by PSF-Canada served as an action plan for interventions and a guiding document for the PSF-Canada pharmacists and the Lacor Hospital pharmacy management team to achieve the vision of the 2008 Basel Statements for hospital pharmacy practice.

The 2008 Basel Statements consisted of 75 consensus statements reflecting a shared vision of the future practice of hospital pharmacy. ${ }^{3}$ The statements were developed in 2008 by an international consortium of 348 pharmacists, from 98 countries, at the 68 th Congress of the FIP. The consensus statements were grouped under 7 themes addressing all areas of hospital pharmacy practice: overarching statements on the future of hospital pharmacy, medication procurement, influences on prescribing, preparation and delivery of medications, administration of medications, monitoring of medications, and human resources and training. The Basel Statements strive for a measure of agreement about the vision of hospital pharmacy practice across borders and across cultures. They have been used to assess or advance hospital pharmacy practice in many areas of the world, including China, Europe, the United States, Canada, Uruguay, the Western Pacific Region, and now Uganda. ${ }^{4-12}$

In May 2010, PSF-Canada deployed its first Canadian pharmacist (G.S.) to put the action plan into motion. Poh and others ${ }^{1}$ published the first part of this illustrative case study, which described the process of utilizing the 2008 Basel Statements in assessing, realigning, and monitoring pharmacy practice at Lacor Hospital from 2010 to 2012. ${ }^{1}$ Collaboration between 
This single copy is for your personal, non-commercial use only.

For permission to reprint multiple copies or to order presentation-ready copies for distribution, contact CJHP at cjhpedit@cshp.ca

Table 1 (part 1 of 4). Status of PSF-Canada Recommendations (2011-2015)

\begin{tabular}{|c|c|c|c|c|}
\hline PSF-Canada Recommendation & April 2011 & June 2012 & May 2013 & September 201 \\
\hline 2009 recommendations & & & & \\
\hline $\begin{array}{l}\text { Establish middle management } \\
\text { positions within the } \\
\text { Department of Pharmacy }\end{array}$ & $\begin{array}{c}\text { In progress } \\
\text { Pharmacy organizational } \\
\text { chart being drafted. }\end{array}$ & $\begin{array}{c}\text { Completed } \\
\text { Designated manager } \\
\text { established for } \\
\text { pharmacy satellites. }\end{array}$ & $\begin{array}{l}\text { Completed } \\
\text { Ongoing accountability } \\
\text { meetings and reporting } \\
\text { will need to be } \\
\text { formalized. }\end{array}$ & Completed \\
\hline
\end{tabular}

\begin{tabular}{lcccc}
\hline Develop a communication & Completed & Completed & Completed & Completed \\
plan to inform clinicians & Weekly or biweekly & Inventory system & Monthly pharmacy & Monthly pharmacy \\
about medication back & reports sent to & reports generated with & bulletins are sent to & bulletins are sent to \\
orders and supply shortages & prescribers. & real-time data; & ward (hard copy and & ward (hard copy and \\
& & information on new & electronic) and & electronic) and \\
& & items or back-ordered & physicians (electronic). & physicians (electronic).
\end{tabular}

medications disseminated,

along with possible alternatives.

\begin{tabular}{lcccc}
\hline Create a buyer position & In progress & In progress & In progress & In progress \\
within the Department of & Purchasing procedure & Recruitment of & In discussion with & Person identified \\
$\begin{array}{l}\text { Pharmacy to support the } \\
\text { procurement of medications }\end{array}$ & being drafted. & procurement officer & senior administrator & and will commence this \\
and medical supplies & & under discussion with & management. Formal & function with pharmacist \\
\hline & & hospital administration. & proposal to be written. & in near future.
\end{tabular}

\begin{tabular}{|c|c|c|c|c|}
\hline $\begin{array}{l}\text { Separate the accounting of } \\
\text { medical supplies from } \\
\text { medications }\end{array}$ & $\begin{array}{c}\text { Completed } \\
\text { Drug utilization report } \\
\text { to be reviewed by } \\
\text { Medicine and } \\
\text { Therapeutics Committee. }\end{array}$ & $\begin{array}{c}\text { Completed } \\
\text { Medications and } \\
\text { medical supplies } \\
\text { recorded, computer- } \\
\text { generated utilization } \\
\text { reports now available } \\
\text { based on category } \\
\text { and location of use. }\end{array}$ & Completed & Completed \\
\hline $\begin{array}{l}\text { Update the drug accounting } \\
\text { process to ensure accuracy } \\
\text { of medication expenditures } \\
\text { at St Mary's Lacor Hospital }\end{array}$ & In progress & $\begin{array}{c}\text { Completed } \\
\text { Drug and medical } \\
\text { supplies expenditures } \\
\text { now available for } \\
\text { each ward or clinic. }\end{array}$ & $\begin{array}{c}\text { Completed } \\
\text { Ongoing system upgrade } \\
\text { needed to integrate } \\
\text { bar-coding system } \\
\text { with current software. }\end{array}$ & Completed \\
\hline
\end{tabular}

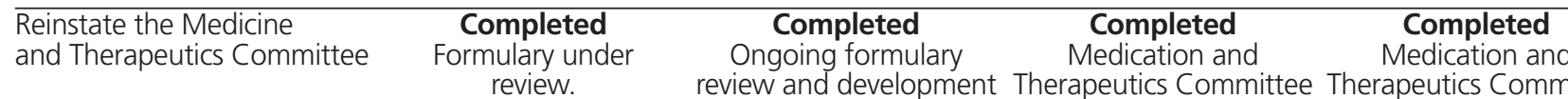
review. review and development Therapeutics Committe of clinical guidelines meets monthly.

for critical care, maternity Clinical prescription and women's health, guidelines published, internal medicine, and second edition pediatrics, and surgery. to be updated. mets mittee meets monthly. Head

pharmacist is secretary of committee. Clinical prescription guidelines published, and second edition to be updated.

\begin{tabular}{lcc}
\hline Create a patient medication & In progress & In progress \\
profile for inpatients and & Ongoing discussions & Ongoing discussions \\
outpatients at St Mary's & with information & with information \\
Lacor Hospital & technology department. & technology department. that thent the
\end{tabular}

In progress
Hospital is reviewing

In progress

ARV/OPD clinical

and updating software pharmacy implemented, outpatients at St Mary's with information
Lacor Hospital patient data and outcome of therapy.

but not others. The hospital is reviewing and updating software that will include the patient's diagnosis, drug therapy, and outcome(s) of therapy.

\begin{tabular}{|c|c|c|c|c|}
\hline $\begin{array}{l}\text { Limit access to pharmacy } \\
\text { stores to designated } \\
\text { pharmacy staff }\end{array}$ & In progress & $\begin{array}{l}\text { Completed } \\
\text { Keys to pharmacy stores } \\
\text { kept in secure location } \\
\text { to which only authorized } \\
\text { personnel have access. }\end{array}$ & $\begin{array}{c}\text { Completed } \\
\text { Locked cabinet with } \\
\text { keys. Only restricted } \\
\text { personnel in main stores. }\end{array}$ & $\begin{array}{c}\text { Completed } \\
\text { Locked cabinet with } \\
\text { keys. Only restricted } \\
\text { personnel in main stores. }\end{array}$ \\
\hline $\begin{array}{l}\text { Review the control of ward } \\
\text { stock medications and } \\
\text { supplies to avoid diversion }\end{array}$ & $\begin{array}{l}\text { In progress } \\
\text { Historical utilization } \\
\text { statistics created. }\end{array}$ & $\begin{array}{c}\text { In progress } \\
\text { Wards have preprinted } \\
\text { order sheets; monthly } \\
\text { audits being conducted; } \\
\text { ongoing audits to } \\
\text { adjust stock levels. }\end{array}$ & $\begin{array}{c}\text { In progress } \\
\text { Initial historical utilization } \\
\text { statistics have been } \\
\text { created and maximum } \\
\text { levels established for each } \\
\text { ward and item. } \\
\text { Ward tracking sheets } \\
\text { have been developed. }\end{array}$ & $\begin{array}{l}\text { Completed } \\
\text { Pharmacy delivery of } \\
\text { ward stock, and ward } \\
\text { stock lists have been } \\
\text { developed outlining } \\
\text { maximum levels of stock } \\
\text { (based on consumption } \\
\text { data). Levels require } \\
\text { continual evaluation. }\end{array}$ \\
\hline
\end{tabular}


This single copy is for your personal, non-commercial use only.

For permission to reprint multiple copies or to order presentation-ready copies for distribution, contact CJHP at cjhpedit@cshp.ca

Table 1 (part 2 of 4). Status of PSF-Canada Recommendations (2011-2015)

\begin{tabular}{|c|c|c|c|c|}
\hline PSF-Canada Recommendation & April 2011 & June 2012 & May 2013 & September 2015 \\
\hline $\begin{array}{l}\text { Utilize the e-learning program } \\
\text { to train nurses and pharmacy } \\
\text { staff on intravenous solution } \\
\text { preparation }\end{array}$ & $\begin{array}{l}\text { Not started } \\
\text { Program being reviewed } \\
\text { with nursing leadership. }\end{array}$ & $\begin{array}{l}\text { Not started } \\
\text { Program being reviewed } \\
\text { with nursing leadership. }\end{array}$ & $\begin{array}{c}\text { Not started } \\
\text { Re-evaluation required } \\
\text { by head pharmacist. }\end{array}$ & $\begin{array}{c}\text { Not started } \\
\text { Re-evaluation required } \\
\text { by head pharmacist. }\end{array}$ \\
\hline $\begin{array}{l}\text { Upgrade the pharmacy } \\
\text { sterile room to meet current } \\
\text { practice standards }\end{array}$ & $\begin{array}{c}\text { Not started } \\
\text { Not cost-effective to } \\
\text { prepare IV solutions locally. }\end{array}$ & $\begin{array}{l}\text { Not started } \\
\text { Recommendation } \\
\text { discontinuation } \\
\text { suggested. }\end{array}$ & $\begin{array}{c}\text { Not started } \\
\text { Not cost-effective to } \\
\text { prepare IV solutions locally. }\end{array}$ & $\begin{array}{c}\text { In progress } \\
\text { Installation of laminar } \\
\text { flow hood, complete } \\
\text { with personal protective } \\
\text { equipment. }\end{array}$ \\
\hline $\begin{array}{l}\text { Provide appropriate training } \\
\text { to staff involved in preparation } \\
\text { and administration of } \\
\text { cytotoxic medications }\end{array}$ & Completed & $\begin{array}{l}\text { Completed } \\
\text { Dilution charts developed, } \\
\text { ongoing quality assurance } \\
\text { and training provided } \\
\text { to meet international } \\
\text { guidelines and standards. }\end{array}$ & Completed & $\begin{array}{c}\text { Completed } \\
\text { Only trained pharmacy } \\
\text { personnel prepare } \\
\text { cytotoxic drugs in room } \\
\text { equipped with laminar } \\
\text { flow hood, complete } \\
\text { with personal } \\
\text { protective equipment. }\end{array}$ \\
\hline $\begin{array}{l}\text { Reassess minimum and } \\
\text { maximum levels for ward } \\
\text { stock medications and } \\
\text { medical supplies on the wards }\end{array}$ & $\begin{array}{c}\text { In progress } \\
\text { Performance indicators } \\
\text { being developed. }\end{array}$ & $\begin{array}{c}\text { Completed } \\
\text { Testing of pharmacy } \\
\text { and ward performance } \\
\text { indicators. }\end{array}$ & $\begin{array}{c}\text { Completed } \\
\text { Ongoing maintenance } \\
\text { needed to validate policy } \\
\text { and keep levels updated. }\end{array}$ & $\begin{array}{c}\text { Completed } \\
\text { Ongoing maintenance } \\
\text { needed to validate policy } \\
\text { and keep levels updated. }\end{array}$ \\
\hline
\end{tabular}

and in the pharmacy

Create a policy detailing

minimum and maximum

levels for ward stock

medications

Increase control and access

to ward stock medications

on wards

Not started

Completed

Standard operating

procedure completed and

under review.

In progress

In progress

Ward stock checklist

being developed.

In progress

ard ordering list rolled Pharmacy delivery of Ward inspection standard out to all wards. ward stock implemented operating procedure on 3 high-volume wards. updated, with biweekly Ward stock lists developed. ward checks performed

by pharmacy staff member.

Assume responsibility for replenishment of ward stock medications

\section{Review infection control}

procedures as they relate to

the administration and

dispensing of medications

at St Mary's Lacor Hospital
Create a strategy to reduce
prescription transcriptions
Not started

In progress

(n)

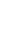

$\begin{array}{cc}\text { of ward stock. } \\ \text { In progress } & \text { In progress } \\ \text { Infection manual } \\ \text { completed, pending } \\ \text { approval by hospital } \\ \text { executive team. }\end{array}$

In progress
Pharmacy delivery of
ward stock implemented
on 3 high-volume wards.
In progress
Infection control
procedures/audit tools con
and checklist required
for dispensing practices
within the pharmacy.

In progress

\section{Completed}

Pharmacy delivery of ward stock to wards.

\section{Completed}

Ward-level infection

control requires audits and

reinforcement from

nursing managers and quality assurance team.

\section{In progress}

Transcription is rarely required, as physicians already write orders directly on the medication administration form.

Development of preprinted order forms for common diagnoses to be explored.

\begin{tabular}{|c|c|c|c|c|}
\hline $\begin{array}{l}\text { Procure smaller-volume } \\
\text { parenteral products for } \\
\text { pediatric patients }\end{array}$ & Completed & Completed & Completed & $\begin{array}{c}\text { Completed } \\
\text { Smaller-volume } \\
\text { IV solutions are procured. }\end{array}$ \\
\hline $\begin{array}{l}\text { Implement a direct refill policy } \\
\text { for outpatients at } \\
\text { St Mary's Lacor Hospital }\end{array}$ & Not started & Discontinued & Discontinued & $\begin{array}{l}\text { Discontinued } \\
\text { Suggest to re-evaluate } \\
\text { at a later date. }\end{array}$ \\
\hline $\begin{array}{l}\text { Conduct a cost-effectiveness } \\
\text { evaluation of in-house, } \\
\text { large-volume parenteral } \\
\text { production }\end{array}$ & & $\begin{array}{l}\text { Con } \\
\text { Not cost effective to } p\end{array}$ & IV solutions locally & \\
\hline $\begin{array}{l}\text { Create a medication } \\
\text { cost-awareness program to } \\
\text { inform clinicians about the } \\
\text { cost of different medical } \\
\text { therapies }\end{array}$ & Not started & $\begin{array}{c}\text { In progress } \\
\text { In discussion with } \\
\text { administration to roll } \\
\text { out clinical guidelines. }\end{array}$ & Completed & Completed \\
\hline
\end{tabular}


This single copy is for your personal, non-commercial use only.

For permission to reprint multiple copies or to order presentation-ready copies for distribution, contact CJHP at cjhpedit@cshp.ca

Table 1 (part 3 of 4). Status of PSF-Canada Recommendations (2011-2015)

\begin{tabular}{|c|c|c|c|c|}
\hline PSF-Canada Recommendation & April 2011 & June 2012 & May 2013 & September 2015 \\
\hline $\begin{array}{l}\text { Conduct a drug-use audit on } \\
\text { high-cost medications to } \\
\text { promote best prescribing } \\
\text { practices at St Mary's Lacor } \\
\text { Hospital }\end{array}$ & $\begin{array}{c}\text { In progress } \\
\text { Ceftriaxone DUE in } \\
\text { pediatric patients under } \\
\text { review. }\end{array}$ & $\begin{array}{c}\text { In progress } \\
\text { Presentation of results to } \\
\text { staff; other DUE } \\
\text { activities being developed. }\end{array}$ & $\begin{array}{c}\text { In progress } \\
\text { DUE completed for } \\
\text { ceftriaxone on pediatric } \\
\text { ward. Next DUE planned. }\end{array}$ & $\begin{array}{c}\text { Completed } \\
\text { Ongoing with periodic } \\
\text { studies of medications. } \\
\text { Projects to be given to } \\
\text { pharmacy students } \\
\text { or interns. }\end{array}$ \\
\hline
\end{tabular}

Create medical directives for

Not started and discontinued

allied health care professionals

2011 recommendations (new)

Conduct an audit of drug

administration to patients,

NA

to evaluate frequency and

rationale for missing

medication doses

$N A$

Follow-up audit

completed, medication

administration form

being revised.
Completed

Ongoing audits required Audits performed annually by quality assurance team with pharmacy support.

with results improving each time. There will be ongoing audits required by quality assurance team with pharmacy support.

Participate on the St Mary's

NA

Completed

Completed

Completed

Lacor pharmacist is a member of infection

Control Committee control committee.

Establish a quality assurance program for nonsterile compounding

In progress

Collaborate with the Lacor School of Nursing to develop and deliver pharmacology sessions for nursing students

\section{In progress \\ Weekly pharmacology \\ courses presented to \\ nursing students}

since 2010 .
In progress

Collaborate with Gulu University to implement and develop pharmacy training programs
Proposal to establish the Pharmacy Program, and Curriculum Development workshops completed in 2010.
In progress guidelines being developed for nonsterile compounding. Completed

Pharmacists involved in teaching pharmacology courses at diploma and certificate level.
Quality assurance

\section{In progress} manual has been updated. Plan for training in place.

\section{Completed}

Local pharmacists and interns are part of teaching team at nursing school. Most teaching now done by pharmacy interns.

\section{In progress}

Pharmacy technician certificate program developed and implemented.

\section{Completed}

PSF-Canada pharmacists support Lacor head and

administrative duties associated with teaching activities at Gulu University. deputy pharmacist with

\section{Completed}

Nonsterile compounding

manual has been updated; pharmacy personnel trained.

\section{Completed}

armacists and pharmacy interns involved in teaching pharmacology courses. Most teaching completed by pharmacy interns.

\section{Completed}

Lacor and PSF-Canada pharmacists assist with administrative duties associated with teaching activities at Gulu University. PharmD program to start in future, depending on human resources and funding.

\section{3 recommendations (new)} NA

NA

NA

NA

C

Increase pharmacist and

NA

pharmacy intern presence and input at ward level and in outpatient areas

\section{Completed}

Significantly improved communication and collaboration with other health care professionals and administrative staff through the distribution of monthly pharmacy

bulletins, presentations during continuing education, involvement in hospital committees, and increased presence on wards.

\begin{tabular}{|c|c|c|c|c|}
\hline $\begin{array}{l}\text { Develop a pharmacy consult } \\
\text { trigger tool to target high-risk } \\
\text { pharmacotherapy issues }\end{array}$ & NA & NA & NA & $\begin{array}{l}\text { Completed } \\
\text { Recommend this as a } \\
\text { project for future interns } \\
\text { or pharmacy students. }\end{array}$ \\
\hline
\end{tabular}

Evaluate the impact of clinical NA NA NA

pharmacy activities (no. of

interventions, time spent

providing drug information,

medication safety, patient

safety, patient education) 
This single copy is for your personal, non-commercial use only.

For permission to reprint multiple copies or to order presentation-ready copies for distribution, contact CJHP at cjhpedit@cshp.ca

Table 1 (part 4 of 4). Status of PSF-Canada Recommendations (2011-2015)

\begin{tabular}{|c|c|c|c|c|}
\hline PSF-Canada Recommendation & April 2011 & June 2012 & May 2013 & September 2015 \\
\hline $\begin{array}{l}\text { Identify high-risk medications } \\
\text { and develop strategies to } \\
\text { increase safety of their use }\end{array}$ & NA & NA & NA & $\begin{array}{c}\text { In progress } \\
\text { High-risk medications } \\
\text { identified in Parenteral } \\
\text { Drug Manual } 2015 . \\
\text { Strategies to be } \\
\text { developed. }\end{array}$ \\
\hline $\begin{array}{l}\text { Implement a system to } \\
\text { monitor and report on } \\
\text { product quality (medicines } \\
\text { and medical supply) }\end{array}$ & NA & NA & NA & $\begin{array}{c}\text { Completed } \\
\text { Standard operating } \\
\text { procedure for } \\
\text { unserviceable condition } \\
\text { reports developed } \\
\text { September 2015; } \\
\text { distribution of form to all } \\
\text { wards and departments }\end{array}$ \\
\hline
\end{tabular}

ARV/OPD = antiretroviral/outpatient department, DUE = drug-use evaluation, NA = not applicable, PSF-Canada $=$ Pharmaciens sans frontières Canada (Pharmacists Without Borders-Canada).

PSF-Canada and Lacor Hospital has been ongoing from 2009 to October 2015. The aim of the current article is to illustrate and highlight the actions taken and accomplishments achieved over a 5-year period, utilizing the 2008 Basel Statements to assess, realign, and monitor pharmacy practice.

\section{PHARMACY ACTION PLAN}

In 2009, 2 PSF-Canada pharmacist advisors (including R.V.) conducted an initial needs-based assessment. An original action plan was developed by PSF-Canada, in conjunction with the Lacor Hospital executive and pharmacy managers, consisting of 24 recommendations (Table 1). The aim of the action plan was to address and close the gaps between current and desired hospital pharmacy practice as envisioned by the 2008 Basel Statements (Table 2).

The first PSF-Canada pharmacist began working at Lacor Hospital in May 2010. In total, the mission consisted of 9 deployments of Canadian pharmacists over the period 2010 to 2015. The mission ended in October 2015. Seven PSF-Canada pharmacists were deployed for periods of 3 to 8 months. Once on site, each PSF-Canada pharmacist was presented with a work plan by the PSF-Canada mission leader, who was located in Canada. The plan included specific goals for the deployment that would advance the mission toward meeting the strategic goals of the PSF-Canada action plan. Every 1 to 2 weeks, the mission leader would connect with the on-site pharmacist, via social media, to review progress and reprioritize goals if required. Details of how each intervention was put into action were not documented, but annual assessments were performed.

To track progress, and to ensure continuity and momentum, the annual mission assessments were conducted annually or biennially from 2010 to 2015 . For these assessments, each of the 2008 Basel Statements was ranked as met, partially met, not met, or not applicable. In addition, each of the PSF-Canada recommendations was ranked according to level of completeness (not started, discontinued, in progress, or completed). After evaluation of each of the 2011 and 2013 assessments, 5 new recommendations were recognized and added to the PSFCanada action plan, for a total of 10 new recommendations (Table 1). Each assessment was conducted by the PSF-Canada mission leader, the head pharmacist at Lacor Hospital, and the PSF-Canada on-site pharmacist. Each assessment included the following elements:

- formal and informal visits to the wards and departments within the hospital, including medicine, pediatrics, maternity, outpatient clinics for adults and children, HIV clinic, outpatient pharmacies (adult, children, private, and HIV clinic), main and inpatient pharmacy stores, IV preparation room, and pharmacy office

- information-gathering through formal and informal interviews

- review of pharmacy workflow processes, inventory management practices, audits, and student project status

Because of the potential for inter-rater bias and the lack of a specific definition for each ranking, the findings were validated through discussion with key individuals, including past PSF-Canada pharmacists and various staff members in the Lacor Hospital, including the executive director, institutional director, medical director, senior administrators, matron, assistant matron, and internal auditors. The presence of these key individuals allowed for consistency in assessment over the years.

\section{INTERVENTIONS}

The majority of the interventions undertaken to achieve the PSF-Canada recommendations, described briefly in Table 1 , were implemented within the hospital's Department of Pharmacy. The implementation strategies to achieve each goal were at the discretion of the on-site PSF-Canada pharmacist, in conjunction with the PSF-Canada mission leader and the Lacor Hospital pharmacy team. Because of the advancement 
This single copy is for your personal, non-commercial use only.

For permission to reprint multiple copies or to order presentation-ready copies for distribution, contact CJHP at cjhpedit@cshp.ca

Table 2 (part 1 of 4). Assessment of Pharmacy Practice St Mary's Lacor Hospital in Relation to 2008 Basel Consensus Statements* $\dagger$

Statement

2012

2013

2015

Overarching statements

1. The overarching goal of hospital pharmacists is to optimize patient outcomes through the judicious, safe, efficacious, appropriate, and cost-effective use of medicines.

2. At a global level, "Good Hospital Pharmacy Practice" guidelines based on evidence should be developed. These guidelines should assist national efforts to define standards across the levels, coverage, and scope of hospital pharmacy services and should include corresponding human resource and training requirements.

3. The "five rights" (the right patient, right medicine, right dose, right route, and right time) should be fulfilled in all medicines-related activities in the hospital.

4. Health authorities and hospital administrators should engage hospita pharmacists in all steps in the hospital medicines-use process.

5. Health authorities should ensure that each hospital pharmacy is supervised by pharmacists who have completed specialized training in hospital pharmacy.

6. The Chief Pharmacist/Director of Pharmacy should be the senior professional responsible for coordinating the judicious, safe, efficacious, appropriate, and cost-effective use of medicines in the hospital.

7. Hospital pharmacists' authority over the medicine-use process should include authority over the selection and use of medicine-related devices such as administration devices, giving sets, infusion pumps, and computer-controlled dispensing cabinets.

8. Hospital pharmacists should take responsibility for all medicines logistics in hospitals

9. Hospital pharmacists should serve as a resource regarding all aspects of medicines use and be accessible as a point of contact for health care providers.

10. All prescriptions should be reviewed, interpreted, and validated by a hospital pharmacist prior to the medicine being dispensed and administered.

11. Hospital pharmacists should monitor patients taking medicines (daily or whenever medicines are changed) to assure patient safety, appropriate medicine use, and optimal outcomes. When resource limitations do not permit pharmacist monitoring of all patients taking medicines, patient-selection criteria should be established to guide pharmacist monitoring.

12. Hospital pharmacists should be allowed to access the full patient record. Partially met Partially met Met Not applicable; requires a national-level assessment

Met

Met

$\begin{array}{llc}\text { Met } & \text { Met } & \text { Met } \\ \text { Met } & \text { Met } & \text { Met }\end{array}$

Met

Met Met Met

Met Met Met

$\begin{array}{llc}\text { Hospital pharmacists should ensure that patients are educated on the } & \text { Met } & \text { Partially met } \\ \text { appropriate use of their medicines. } & & \text { Met } \\ \text { Hospital pharmacists should provide orientation and education } & \text { Met } & \text { Met }\end{array}$

14. Hospital pharmacists should provide orientation and education for medicines use.

15. Undergraduate pharmacy curricula should include hospital-relevant_Partially met Partially met Partially met content, and post-graduate training programs and specializations in hospital pharmacy should be developed.

16. Hospital pharmacists should actively engage in research into new methods and systems to improve the use of medicines.

\begin{tabular}{llc} 
Met & Met & Met \\
\hline Met & Met & Met
\end{tabular}

Not met $\quad$ Not met $\quad$ Partially met

Not met $\quad$ Partially met Partially met

\begin{tabular}{|c|c|c|}
\hline Met & Met & Met \\
\hline Met & Partially met & Met \\
\hline Met & Met & Met \\
\hline Partially met & Partially met & Partially met \\
\hline Partially met & Met & Met \\
\hline
\end{tabular}

continued on page 41

of the hospital's Department of Pharmacy, it became a location for both Canadian and Ugandan pharmacy students to complete rotations for their professional programs. The students completed projects that supported the Department of Pharmacy in achieving the PSF-Canada recommendations. Examples of student projects included updating the Parenteral Drug Manual, completing drug-use evaluations, completing clinical intervention investigations, and developing standard operating procedures used to train staff in handling cytotoxic drugs. In 2011, a pharmacy certification program was instituted under the auspices of the Gulu University Faculty of Medicine. Through this accomplishment, Lacor Hospital became one of the training centres for the pharmacy technician certification and diploma programs. Details of these accomplishments are presented under "human resources and training" in Table 3.

To aid in the sustainability of procedural interventions, standard operating procedures were developed for specific processes, such as ward inspections and completion of unserviceable 
This single copy is for your personal, non-commercial use only.

For permission to reprint multiple copies or to order presentation-ready copies for distribution, contact CJHP at cjhpedit@cshp.ca

Table 2 (part 2 of 4). Assessment of Pharmacy Practice St Mary's Lacor Hospital in Relation to 2008 Basel Consensus Statements* $\dagger$

Statement

2012

2013

2015

Medicines procurement

17. The procurement process must be transparent, professional, and ethical to promote equity and access and to ensure accountability to relevant governing and legal entities.

18. Procurement should be guided by the principle of procuring for safety.

19. Procurement of pharmaceuticals is a complex process that requires pharmacist control and technically competent staff.

20. Operational principles for good procurement practice should be regularly Met reviewed and procurement models adapted to fit different settings and emerging needs in the most appropriate and cost-effective way.

21. Procurement must be supported by strong quality assurance principles to ensure that poor quality medicines are not procured or allowed into the system. Proper storage to ensure maintenance of quality in the whole supply pipeline is mandatory.

22. Procurement should not occur in isolation, but rather be informed by the formulary selection process.

23. Good procurement must be supported by a reliable information system that provides accurate, timely, and accessible information.

24. A formal mechanism must be in place for pharmacists to request designated funds to procure medicines for their patients.

25. Each pharmacy should have contingency plans for medicines shortages and purchases in emergencies.

\section{Influences on prescribing}

26. Hospitals should utilize a medicine formulary system (local, regional, and/or national) linked to standard treatment guidelines, protocols, and treatment pathways based on the best available evidence.

27. Hospital pharmacists should be members of pharmacy and therapeutics committees to oversee all medicines management policies and procedures, including those related to off-label use and investigational medicines.

28. Hospital pharmacists should have a key role in educating prescribers at all levels of training on the access to and evidence for optimal and appropriate use of medicines, including the required monitoring parameters and subsequent prescribing adjustments.

29. Hospital pharmacists should be involved in all patient care areas to prospectively influence collaborative therapeutic decision-making

30. Hospital pharmacists should be an integral part of all patient rounds to assist with therapeutic decision-making and advise on clinical pharmacy and patient safety issues.

31. Hospital pharmacists should provide continuity of care by transferring patient medicines information as patients move between sectors of care.

Preparation and delivery of medicines

33. Hospital pharmacists should ensure that proper storage conditions are provided for all medicines used in the hospital.

34. Hospital pharmacists should assume responsibility for the appropriate labelling and control of medicines stored throughout the hospital.

35. Hospital pharmacists should ensure that compounded medicines are consistently prepared to comply with quality standards.

36. Hospital pharmacists should provide pharmacy-managed injectable admixture services using aseptic technique.

37. Hazardous medicines, including cytotoxics, should be prepared under environmental conditions that minimize the risk of contaminating the product and exposing hospital personnel to harm.

41. Hospital pharmacists should implement systems for tracing medicines dispensed by the pharmacy (to facilitate recalls, for example).

Met Met Met

$\begin{array}{lll}\text { Met } & \text { Met } & \text { Met } \\ \text { Met } & \text { Met } & \text { Met }\end{array}$

Met Met Met

Met

Met

Met

Met Met Met

Met Partially met Met

Met Met Met

Met Met Met

Met Met Met

Partially met Partially met Met

$\begin{array}{lccc} & & & \\ & \text { Partially met } & \text { Partially met } & \text { Partially met } \\ & \text { Not met } & \text { Not met } & \text { Partially met }\end{array}$


This single copy is for your personal, non-commercial use only.

For permission to reprint multiple copies or to order presentation-ready copies for distribution, contact CJHP at cjhpedit@cshp.ca

Table 2 (part 3 of 4). Assessment of Pharmacy Practice St Mary's Lacor Hospital in Relation to 2008 Basel Consensus Statements* $\dagger$

Statement

2012

2013

2015

\section{Administration of medicines}

42. Hospital pharmacists should ensure that the information resources needed for safe medicines preparation and administration are accessible at the point of care.

43. Hospital pharmacists should ensure that allergies are accurately recorded in a standard location in patient records and evaluated prior to medicines administration.

44. Hospital pharmacists should ensure that medicines are packaged and labelled to ensure identification and to maintain integrity until immediately prior to administration to the individual patient.

45. Where medicines are labelled for individual patients, full details to ensure safe administration should be included, for example, name of medicine, route, and, where appropriate, dose in mass and volume.

46. Storage of concentrated electrolyte products (such as potassium chloride and sodium chloride) and other high-risk medicines on patient wards should be eliminated by dispensing ready-to-administer dilutions, or, if necessary, storing such products distinctly labelled in separate or secure areas.

47. Health care professionals responsible for administering injectable medicines and chemotherapy should be trained in their use, hazards, and necessary precautions.

48. Doses of chemotherapy and other designated medicines (based upon risk assessment) should be independently checked against the original prescription by two health care professionals at the point of care prior to administration.

49. Pharmacists should ensure that strategies and policies are implemented to prevent wrong route errors, including, for example, labelling of intravenous tubing near insertion site to prevent misconnections, and use of enteral feeding catheters that cannot be connected with intravenous or other parenteral lines.

50. Vinca alkaloids should be diluted, ideally in a minibag and/or large syringe (for pediatric patients), and dispensed with special labelling precautions in order to prevent inadvertent intrathecal administration.

52. Medicines not commercially available for neonatal and pediatric patients should be prepared by the hospital pharmacy.

53. Standard concentrations of medicines should be determined, procured, and prepared for all patients, and especially for pediatric, neonatal, and critical care patients.

54. Hospital pharmacists should be responsible for determining which medicines are included in ward stock and for standardizing the storage and handling of ward medicines.

55. Hospital pharmacists should develop simple, rules-based approaches to advancing patient safety; for example, when a large number of dosage units are needed to give a dose (more than two tablets, vials, etc.), the prescription should be verified prior to administration.

56. Hospital pharmacists should ensure the development of quality assurance strategies for medicines administration, including the use of observation methodology to detect errors and identify priorities for improvement.

57. The medicines administration process should be designed such that transcription steps between the original prescription and the medicines administration record are eliminated.

Partially met Met Met

Not met $\quad$ Partially met Met

Not met

Not met

Not met

outpatient outpatient outpatient

department department department

Met Met Met

Partially met $\quad$ Not met $\quad$ Partially met

Not met

Not met $\quad$ Not met Met

Met Met Met

Partially met Partially met Partially met Met Met Met

Not met Not met Not met

Partially met Partially met Partially met

(1)

Met

Met

Met 
This single copy is for your personal, non-commercial use only.

For permission to reprint multiple copies or to order presentation-ready copies for distribution, contact CJHP at cjhpedit@cshp.ca

Table 2 (part 4 of 4). Assessment of Pharmacy Practice St Mary's Lacor Hospital in Relation to 2008 Basel Consensus Statements* $\dagger$

Statement

2012

2013

2015

Monitoring of medicines

58. A reporting system for defective medicines should be established and Not applicable Not met Met maintained to monitor and take the necessary action to minimize identified risks. Reports of defective or substandard medicines should be sent to regional or national pharmacovigilance reporting programs where these are available.

59. A reporting system for adverse drug reactions should be established and maintained, and the necessary action should be taken to minimize identified risks. Reaction reports should be sent to regional or national pharmacovigilance reporting programs where these are available.

60. A reporting system for medication errors should be established and maintained, and the necessary action should be taken to minimize identified risks. Reports of medication errors should be sent to regional or national medication error reporting programs where these are available.

61. Hospital medication practice should be self assessed and data trended internally and compared with best practice in other institutions to improve safety, clinical effectiveness, and cost-effectiveness.

62. Hospital medication practices should be reviewed by an external quality assessment accreditation program. Hospitals should act on reports following regular external quality assessment inspections to improve the quality and safety of their practices.

63. Pharmacists' clinical interventions should be documented in the patient record. These data should be regularly analyzed to improve the quality and safety of medication practice.

64. Trigger tools should be used to provide quantitative data on adverse drug events in the hospital. These data should be regularly reviewed to improve the quality and safety of medication practices.

65. Advanced clinical pharmacy services should manage medication therapy to optimize therapeutic outcomes. Outcomes data from such programs should be regularly reviewed and used to improve the quality and safety of medication practices. Examples include management of anticoagulation therapy, antimicrobial therapy, and therapeutic drug monitoring.

\section{Human resources and training}

68. Hospital pharmacy human resource plans should cover all cadres and be linked to health targets. Such plans should describe strategies for human resource education and training, recruitment and retention, competency development, salary and career progression pathways, gender-sensitive policies, equitable deployment and distribution, management, and roles and responsibilities of stakeholders for implementation.

75. The hospital pharmacy human resource evidence gap should be explored and addressed through a strategic research agenda.

${ }^{\star}$ The assessments for 2009 and 2011 can be found in part 1 of this illustrative case study (Poh et al. ${ }^{1}$ ).

†The following 2008 Basel consensus statements did not apply or were not attainable during this PSF-Canada mission and are therefore omitted from this table: 32, 38-40, 51, 66, 67, 69-74.

condition reports. In addition to these documented standard operating procedures, the overall increased knowledge and experience of the current Lacor Hospital pharmacy and executive teams will aid in the continuity of interventions as well as the future improvement of procedures and education of staff. Significantly improved communication and collaboration with other health care professionals and administrative staff, through the distribution of monthly pharmacy bulletins, publication of the Parenteral Drug Manual, presentations during continuing education events, involvement in hospital committees, and increased presence on wards, will aid in sustaining clinical knowledge and continuity of a higher level of pharmacy care and support for patients.

\section{PROGRESSION OF PHARMACY PRACTICE AT ST MARY'S LACOR HOSPITAL}

A quantitative analysis of progress in relation to the 2008 Basel Statements at Lacor Hospital is summarized in Table 4. From 2009 to 2015, the number of fully achieved (status of "met") statements climbed from 18 (24\%) to 44 (59\%). In 
This single copy is for your personal, non-commercial use only.

For permission to reprint multiple copies or to order presentation-ready copies for distribution, contact CJHP at cjhpedit@cshp.ca

Table 3. Major Accomplishments by the PSF-Canada Uganda Mission, 2010-2015

Area

Accomplishments and Highlights

Professional standards Significant improvements in interprofessional and interstaff communication and collaboration:

and communication $\quad$ - distribution of monthly pharmacy bulletins

- pharmacy presentations during continuing medical education sessions

- pharmacy department staff involvement in hospital committees

- increased presence of pharmacy staff on wards

Inventory procurement Local staff trained to independently complete the following activities with more precision:

and management $\quad \bullet$ perform daily inventory management

- quarterly stock taking

New computer work stations established in the pharmacies and pharmacy department

Decline in inventory discrepancies for medical drugs and sundries over the past 5 years: in the past

2 years (FY 2013/2014 and FY 2014/2015), an international external auditor gave St Mary's Lacor Hospital a clean financial report and audit

Preparation and delivery Organization and streamlining of ward stock using preprinted ward order books

of medications

Development of ward stock lists and audit tools

Pharmacy delivery of medications and medical supplies to wards

Development and implementation of standard operating procedures and training for cytotoxic drugs

and nonsterile compounds

Installation of laminar flow hood, complete with personal protective equipment

Prescribing and

Revival of the Medicines and Therapeutics Committee:

medication use $\quad$ published institutional clinical guidelines

- implemented cost-awareness program

- conducted a formulary review

- quality improvement research such as drug prescription audits completed and continued

- drug use evaluations performed and will continue

The hiring of pharmacy technicians and the presence of the pharmacy interns have increased

the presence of trained personnel in the pharmacies and wards

Administration of Drug administration audits completed, with areas of improvement identified

medications $\quad$ Parenteral Drug Manual, third edition (2015) complete for all injectable drugs used at St Mary's Laco

Hospital; manual distributed to wards, departments, pharmacies, and peripheral health care centres

Quality assurance committee established

Monitoring and

pharmacovigilance

Adverse drug reaction reports completed and reported regularly

Standard operating procedure for unserviceable condition reports established; form distributed to wards and departments for use by all medical staff

Human resources Middle management positions created for each of the pharmacy satellites

and training Main pharmacy staffing increased: 1 receiver, 1 data entry clerk

Two nursing aides completed the Ecumenical Pharmacy Network pharmacy certificate program

Two to four pharmacy interns per year provide clinical and technical pharmacy support

Collaboration with Gulu University Pharmacy Program: pharmacists are integrated into teaching

of diploma and certificate students; students are sent to St Mary's Lacor Hospital and the 3 peripheral

health care centres as part of their training

Ministry of Health consults with pharmacy managers and Pharmaceutical Society of Uganda

$\overline{F Y}=$ fiscal year, PSF-Canada $=$ Pharmaciens sans frontières Canada (Pharmacists Without Borders—Canada).

\section{Table 4. Quantitative Analysis of Status of Pharmacy Practice in Relation to the 2008 Basel Consensus Statements at St Mary's Lacor Hospital, Gulu, Uganda}

\begin{tabular}{lccccc} 
& \multicolumn{5}{c}{ Year of Assessment; No. of Statements } \\
\cline { 2 - 5 } Status & $\mathbf{2 0 0 9}$ (Baseline) & $\mathbf{2 0 1 1}$ & $\mathbf{2 0 1 2}$ & $\mathbf{2 0 1 3}$ & $\mathbf{2 0 1 5}$ \\
\hline Not applicable & 18 & 16 & 14 & 13 & 13 \\
Not met & 25 & 15 & 12 & 13 & 4 \\
Partially met & 14 & 19 & 14 & 14 & 14 \\
Met & 18 & 25 & 35 & 35 & 44 \\
Total & 75 & 75 & 75 & 75 & 75 \\
\hline
\end{tabular}

addition, 14 statements achieved the status of "partially met", increasing the success of the mission. The number of "not applicable" statements was reduced from 18 (24\%) in 2009 to $13(17 \%)$ in 2015. Seven of the 13 statements ranked "not applicable" revolved around human resources and training and thus required national-level collaboration. That level of collab- oration was beyond reach for the hospital and for this particular PSF-Canada mission.

The status of each PSF-Canada recommendation is detailed in Table 1. The original 24 PSF-Canada recommendations, which were the backbone of the PSF-Canada action plan, grew to a total of 34 recommendations, with the addition 
of 5 new recommendations following each of the 2011 and 2013 assessments (as described above). Twenty-three of these 34 PSF-Canada recommendations were completed over 5 years, with another 6 currently in progress.

\section{DISCUSSION}

This illustrative case study supports the use of the 2008 Basel Statements for baseline assessment, as well as implementation and follow-up of interventions to meet the preferred vision of practice for hospital pharmacy. The vision of the Basel Statements parallels the FIP mission to "improve global health by advancing pharmacy practice and science to enable better discovery, development, access to and safe use of appropriate, cost-effective, quality medicines worldwide." 3,13

Since their original dissemination in 2009, the Basel Statements have been utilized in both developed and developing countries to assess, advance, or implement hospital pharmacy practice. ${ }^{4-12}$ For example, shortly after circulation of the 2008 Basel Statements, the Paraguay-Uruguay project was developed to implement the Good Hospital Pharmacy Practice plan of these 2 countries using the Basel Statements and the FIP vision as core influences to develop their strategic goals. ${ }^{5}$ In the Western Pacific Region, Penm and others ${ }^{6,7}$ have completed projects focusing on pharmacists' influence on prescribing and validating a hospital medicines formulary, using surveys to validate the achievement of specific sections of the Basel Statements. Pharmacists in China have changed their vision of pharmacy practice, moving from a focus on drug products to an emphasis on caring for patients, consistent with the vision that emerged from the 2008 Basel Statements. ${ }^{8}$ The European Association of Hospital Pharmacists used the Basel Statements when developing its statements on hospital pharmacy practice. ${ }^{10}$ Most recently, Lyons and others ${ }^{11}$ attempted to develop and pilot an assessment tool that institutions in a single country or across multiple countries can use to evaluate their pharmacies' performance against the standards of the 2008 Basel Statements. In addition, the Basel Statements have been shown in both the United States and Canada to have a high degree of alignment with the standards of pharmacy practice of the American Society of Health-System Pharmacists and the Canadian Society of Hospital Pharmacists. ${ }^{12}$

The diversity in assessment and implementation techniques in different countries and regions demonstrates that medication safety requires commitment at the national, regional, hospital, pharmacy, pharmacist, and pharmacy technician levels. It also supports the FIP's acknowledgement that it could not develop a simple "cook book" approach that could be applied in all settings. ${ }^{4}$ In September 2015, an updated version of the Basel Statements was launched, consisting of 65 statements. ${ }^{14}$ The revisions more closely align the statements with the WHO guidelines on good pharmacy practice and have a greater ability to account for the diversity of settings in which these statements may be implemented. ${ }^{2,14,15}$

This illustrative case study had 3 limitations. First, we were unable to assess the Lacor Hospital's progress in relation to 13 of the Basel Statements (see Table 2). Eight of these 13 statements ranked as "not applicable" fall within the same theme, human resources and training. To achieve these criteria, a national-level assessment involving multiple stakeholders would be required, but such an assessment was not realistic for Lacor Hospital, nor was it within the scope of the PSF-Canada mission. The other 5 "not applicable" statements were related to areas that did not exist in or were not feasible for Lacor Hospital at the time, including enhanced pharmacy technology (e.g., unit-dose distribution systems) and investigational medications for research purposes. Second, use of the terms "partially met" and "in progress" to rank the status of the 2008 Basel Statements and the PSF-Canada recommendations, respectively, allowed inter-rater variability and subjectivity. In this case study, the assessors were the PSF-Canada mission leader and the on-site PSF-Canada pharmacist. The individuals holding these positions changed over time, which left room for different interpretations of the terminology at the time of assessment. Finally, the on-site PSF-Canada pharmacists were responsible for both the interventions to meet the prescribed goals and assessments of the outcome of these interventions, a situation that may introduce bias. Given the limited resources available for this PSF-Canada mission, seeking assessments from external or independent reviewers was not feasible. To overcome the potential bias, validation of the assessments was completed by many other key individuals, including past PSF-Canada pharmacists and St Mary's Lacor Hospital staff members, such as the executive director, institutional director, medical director, senior administrators, matron, assistant matron, and internal auditors.

In addition to the first illustrative case study published by Poh and others ${ }^{1}$ in 2013, other publications have described the use of specific sections of the Basel Statements to influence areas of hospital pharmacy practice. ${ }^{4-12}$ However, to the authors' knowledge, the current report is only the second descriptive study illustrating use of the majority of the 2008 Basel Statements as a framework to assess, realign, and monitor pharmacy practice in a tertiary care hospital. Given the recent updates to the Basel Statements, more documented use of the statements to assess and improve hospital pharmacy practice is required.

\section{CONCLUSION}

This case study illustrates use of the FIP's 2008 Basel Statements to align a hospital's goals for assessment, implementation, and improvement of hospital pharmacy practice. With the revisions to the Basel Statements that were released in 2015, more documented validation is required to verify the observations reported here. As recognized by the FIP, "It is important 
that we take these statements beyond our own profession and make other healthcare colleagues aware of our aspirations. Furthermore, our administrators and politicians know that we have these standards and that we need their support to promote and implement them in the interest of patients." ${ }^{4}$

\section{References}

1. Poh J, Vaillancourt R, Lamarre D, Oyella J. Use of the 2008 Basel consensus statements to assess, realign, and monitor pharmacy practice at a tertiary care hospital in Northern Uganda: illustrative case study. Can J Hosp Pharm. 2013;66(5):318-27.

2. Annex 8: Joint FIP/WHO guidelines on good pharmacy practice: standards for quality of pharmacy services. In: Forty-fifth report of the WHO Expert Committee on specifications for pharmaceutical preparations. WHO Tech Rep Ser 961. Switzerland (Geneva): World Health Organization; 2011 [cited 2016 Feb]. pp. 310-23. Available from: http://apps.who.int/medicinedocs/ documents/s18676en/s18676en.pdf

3. The Basel statements on the future of hospital pharmacy. Am J Heath Syst Pharm. 2009;66(5 Suppl 3):S61-6.

4. Gray A, Tredree R. Implementing the Basel statements on the future of hospital pharmacy: a global challenge. Int Pharm J. 2010;26(2):32-4.

5. Savio E, Fernández G, Omos V, Daners M, Gerpe N. FIP Basel statements and the future of hospital pharmacy services in Uruguay. Int Pharm J. 2010;26(2):39-41.

6. Penm J, Chaar B, Moles R. Validating a hospital medicines formulary survey in the Western Pacific Region - a global hospital pharmacy initiative based on the Basel Statements. Res Social Adm Pharm. 2012;8(4):298-308.

7. Penm J, Chaar B, Rose G, Moles R. Pharmacists' influences on prescribing: validating a clinical pharmacy services survey in the Western Pacific Region. Res Social Adm Pharm. 2015;11(1):63-73.

8. DeChun J, YuQuin W, SuYing Y, XiaoLan L, Hong G, YaWei W. A comparison of Chinese hospital pharmacy practice and the Basel statements. Int Pharm J. 2010;26(2):42-4.

9. Zellmar WA, Hawkins B. The Basel statements as stimulus for advancement of hospital pharmacy in a developed country. Int Pharm J. 2010;26(2):44-6.

10. Vermeulen L. From Basel to Brussels: the FIP Basel Statements as the foundation of the EAHP Statements of Hospital Practice. Eur J Hosp Pharm. 2014;21(5):262-3

11. Lyons K, Blalock SJ, Brock TP, Manasse HR Jr, Eckel SF. Development of a global hospital self-assessment tool and prioritization tier system based on FIP's Basel Statements. Int J Pharm Pract. 2016;24(2):123-33.

12. Wright A, Vaillancourt R, Bussières JF, Lebel D, Wong E, Mancini D, et al. Best of both worlds: a comparison of Canadian and international best practices for hospital pharmacy services. Can J Hosp Pharm. 2015;68(1):48-53.

13. Who we are and what we do. The Hague (Netherlands): International Pharmaceutical Federation; [cited 2016 Feb]. Available from: www.fip.org/ ?page=menu_about

14. Revised FIP Basel Statements on the future of hospital pharmacy. The Hague (Netherlands): International Pharmaceutical Federation, Hospital Pharmacy Section; 2014 [cited 2016 Feb]. Available from: http://fip.org/files/fip/ FIP_BASEL_STATEMENTS_ON_THE_FUTURE_OF_HOSPITAL_ PHARMACY_2015.pdf

15. Thompson CA. FIP Hospital Pharmacy Section releases new version of Basel statements. Am J Health Syst Pharm. 2015;72(22):1924-5.
Danielle Stacey, BScPharm, PharmD, is a Pharmacy Officer with the Canadian Forces Health Services Training Center, Department of National Defence, Borden, Ontario.

Régis Vaillancourt, BPharm, PharmD, FCSHP, FFIP, is Director of Pharmacy, Children's Hospital of Eastern Ontario, Ottawa, Ontario. He is also President of Pharmaciens sans frontières-Canada.

Lisa Brander, BScPharm, is a Medical Logistician, Emergency Response Unit, Canadian Red Cross, Edmonton, Alberta. She is also Vice-President of Pharmaciens sans frontières-Canada.

Nathalie Chenel, BPharm, MSc, is a Pharmacist with Hôpital régional de Rimouski, Centre intégré de santé et de services sociaux de Bas-Saint-Laurent, Rimouski, Québec.

Elizabeth McMahon, BScPharm, is an Emergency Response Delegate with the Canadian Red Cross, Bedford, Nova Scotia.

Jennifer Wiebe, BScPharm, MPH, is a Pharmacist with St Boniface Hospital, Winnipeg, Manitoba.

Allison Kirkwood, BSC(Pharm), ACPR, MHA, is a Clinical Associate with the Medication Management Team, Clinical and Systems Transformation Project, Vancouver Coastal Health-Providence Health Care and Provincial Health Services Authority, Vancouver, British Columbia.

Ghada Shaka, BScPharm, is a Pharmacist with St Joseph's Healthcare Hamilton, Hamilton, Ontario.

Doret Cheng, BScPharm, PharmD, is Lecturer and Experiential Education Coordinator with the Leslie Dan Faculty of Pharmacy, University of Toronto, Toronto, Ontario.

Lisa Brander, Nathalie Chenel, Elizabeth McMahon, Jennifer Wiebe, Allison Kirkwood, Ghada Shaka, and Doret Cheng volunteered their time and expertise while serving Pharmaciens sans frontières-Canada (PSF-Canada) as consultant pharmacists at St Mary's Lacor Hospital in the Gulu District of Northern Uganda.

\section{Address correspondence to:}

Dr Régis Vaillancourt

Department of Pharmacy

Children's Hospital of Eastern Ontario

401 Smyth Road

Ottawa ON K1H 8L1

e-mail: rvaillancourt@cheo.on.ca

Funding: In addition to serving as volunteers, Lisa Brander, Elizabeth McMahon, and Ghada Shaka received wages from PSF-Canada while working on the Uganda mission. PSF-Canada is supported by the TeasdaleCorti Foundation and the Marcelle and Jean Coutu Foundation.

Competing interests: Other than wages listed above, no other competing interests were declared.

Acknowledgements: The authors would like to thank Caroline Potvin for serving as a leader and advisor for the Pharmaciens sans frontièresCanada mission in Uganda and Diane Lamarre for aiding in initial on-site assessment and in development of the original action plan. 